\title{
Development of microsatellite markers for the endangered sleeper Eleotris oxycephala (Perciformes: Eleotridae)
}

\author{
Uchu Yamakawa ${ }^{1}$, Shingo Kaneko ${ }^{2}$, Ryosuke Imai ${ }^{1 \dagger}$, Leanne Kay Faulks ${ }^{1}$, \\ Koetsu Kon ${ }^{3}$, Daisuke Kyogoku ${ }^{4 \ddagger}$, Yuji Isagi ${ }^{4}$ and Yoshiaki Tsuda ${ }^{1 *}$ \\ ${ }^{1}$ Sugadaira Research Station, Mountain Research Center, University of Tsukuba, 1278-294 Sugadairakogen, \\ Ueda, Nagano 386-2204, Japan \\ ${ }^{2}$ Faculty of Symbiotic Systems Science, Fukushima University, 1 Kanayagawa, Fukushima, \\ Fukushima 960-1296, Japan \\ ${ }^{3}$ Shimoda Marine Research Center, University of Tsukuba, 5-10-1 Shimoda, Shizuoka \\ 415-0025, Japan \\ ${ }^{4}$ Graduate School of Agriculture, Kyoto University, Kitashirakawa Oiwake-cho, \\ Sakyo-ku, Kyoto, Kyoto 606-8502, Japan
}

(Received 9 April 2019, accepted 22 May 2019; J-STAGE Advance published date: 16 November 2019)

The amphidromous sleeper Eleotris oxycephala (Perciformes: Eleotridae) is mainly distributed along the Kuroshio Current in East Asia, and this current is thought to be the main driver of the species' dispersal. Due to anthropogenic environmental changes in rivers, E. oxycephala is ranked as a threatened or near-threatened species in the red lists of 12 prefectures in Japan. Moreover, there is concern that the species' dispersal pattern could be changed due to fluctuations in the Kuroshio Current caused by global warming. In this study, 40 microsatellite markers were developed for E. oxycephala, and their suitability was tested on 43 individuals from two populations of E. oxycephala from Kanagawa and Miyazaki Prefectures. The number of alleles, expected heterozygosity and fixation index at each locus were $2-10($ mean $=5.350), 0.034-0.860($ mean $=0.650)$ and $-0.261-0.448($ mean $=$ 0.065), respectively. Furthermore, there was a lack of genetic difference between the two populations $\left(F_{\mathrm{ST}}=0.008, F_{\mathrm{ST}}=0.024\right)$, indicating widespread gene flow via the Kuroshio Current. These markers will be useful to evaluate the genetic structure and infer population demographic history of E. oxycephala populations, which may assist in the conservation of this species.

Key words: conservation, Eleotris oxycephala, endangered sleeper, Kuroshio Current, microsatellites

Amphidromous fish species, requiring freshwater and marine environments to complete their life history, have been adversely affected by recent environmental changes. Human alterations such as dam construction and stream modification (Ministry of Land, Infrastructure, Transport and Tourism, 2018 [http://www.mlit.go.jp/river/ $\mathrm{dam} / \mathrm{pdf} / \mathrm{H} 30 \mathrm{dam} . \mathrm{pdf}]$ ) are the main causes of the continued decrease in suitable habitat for aquatic organisms including amphidromous fishes (Katano et al., 2006). In addition to freshwater environmental changes, seawater

\footnotetext{
Edited by Yoshihiko Tsumura

* Corresponding author. E-mail: ytsuda.gt@gmail.com

$\uparrow$ Present address: Iriomote Station, Tropical Biosphere Research Center, University of the Ryukyus, 870 Uehara, Taketomi-cho, Yaeyama-gun, Okinawa 907-1541, Japan

$\ddagger$ Present address: Research Institute for Food and Agriculture, Ryukoku University, Otsu, Shiga 520-2194, Japan

DOI: http://doi.org/10.1266/ggs.19-00007
}

temperature rise due to global warming is continuing (IPCC, 2013), and could alter the distribution of various aquatic organisms including amphidromous fishes, for example, Eleotris fusca (Forster, 1801) and Ophieleotris sp. 1 of Akihito et al., 2013 (Yamakawa et al., 2018). Furthermore, ocean current fluctuations are predicted to occur in the near future (Sakamoto et al., 2005; Chang et al., 2018), potentially altering the dispersal patterns of aquatic organisms that disperse using ocean currents (e.g., Anguilla japonica Temminck and Schlegel, 1847; Chang et al., 2018). This change in dispersal patterns could alter gene flow among populations, which is related to the maintenance of genetic diversity, and this in turn could disrupt reproductive patterns and local population adaptation. Indeed, patterns of gene flow and genetic diversity of many fishes, including amphidromous species, are influenced by dispersal via ocean currents (e.g., Watanabe et al., 2006; Shaddick et al., 2011; Kuriiwa et 
Table 1. Characteristics of 40 microsatellite primers developed for Eleotris oxycephala

\begin{tabular}{|c|c|c|c|c|c|c|c|}
\hline Locus & $\begin{array}{l}\text { Multiplex } \\
\text { panel }\end{array}$ & Primer sequences $\left(5^{\prime}-3^{\prime}\right)$ & $\begin{array}{l}\text { Repeat } \\
\text { motif }\end{array}$ & $T_{\mathrm{a}}\left({ }^{\circ} \mathrm{C}\right)$ & $\begin{array}{l}\text { Fluorescent } \\
\text { label }^{\mathrm{a}}\end{array}$ & $\begin{array}{l}\text { Size range } \\
\quad(b p)\end{array}$ & $\begin{array}{c}\text { GenBank } \\
\text { accession no. }\end{array}$ \\
\hline Eoxy002 & $\mathrm{E}$ & $\begin{array}{l}\text { F: GCCAGCTCCAACACGTTTAT } \\
\text { R: AACAGGGCAGTGTTTCATCC }\end{array}$ & $(\mathrm{ATC})_{12}$ & 57 & PET & $179-209$ & LC462952 \\
\hline Eoxy008 & $\mathrm{F}$ & $\begin{array}{l}\text { F: ACAGCTGCACCACACTCAAC } \\
\text { R: ACGCAGGGCTTTACTTTACG }\end{array}$ & $(\mathrm{GT})_{9}$ & 57 & FAM & $109-113$ & LC462953 \\
\hline Eoxy009 & $\mathrm{F}$ & $\begin{array}{l}\text { F: TTTGCCAACTGGCTGTGTTA } \\
\text { R: GATCAAACGCTGGAGAAGGA }\end{array}$ & $(\mathrm{AC})_{9}$ & 57 & NED & $154-160$ & LC462954 \\
\hline Eoxy010 & $\mathrm{C}$ & $\begin{array}{l}\text { F: GGATTGAGCCAGATGATGGT } \\
\text { R: CATTTCCGTGTATCCAACCC }\end{array}$ & $(\mathrm{TG})_{8}$ & 57 & VIC & $179-185$ & LC462955 \\
\hline Eoxy013 & $\mathrm{F}$ & $\begin{array}{l}\text { F: GGCACCCAGTGGAGACTTTA } \\
\text { R: CTTGCTGAAAGATGAGCGTG }\end{array}$ & $(\mathrm{AT})_{8}$ & 57 & PET & $129-159$ & LC462956 \\
\hline Eoxy015 & $\mathrm{E}$ & $\begin{array}{l}\text { F: GACAGACGCTCTGATCCCAT } \\
\text { R: CCGGTCTTTGAGAACCTCTG }\end{array}$ & $(\mathrm{AG})_{8}$ & 57 & VIC & $118-123$ & LC462957 \\
\hline Eoxy016 & $\mathrm{D}$ & $\begin{array}{l}\text { F: CTCTGATTGGAGGAGACGGA } \\
\text { R: ATACCCAACATCCCAAACCA }\end{array}$ & $(\mathrm{AG})_{8}$ & 57 & PET & $230-232$ & LC462958 \\
\hline Eoxy025 & B & $\begin{array}{l}\text { F: TGCTGACCTGCTGTTCATGT } \\
\text { R: CCTCTCGACGTCTTCACTCC }\end{array}$ & $(\mathrm{AGG})_{7}$ & 57 & NED & $113-128$ & LC462959 \\
\hline Eoxy027 & B & $\begin{array}{l}\text { F: CAGGAAGCAGGTGGTTTGTT } \\
\text { R: CCATTTCTCATCGCTCGTCT }\end{array}$ & $(\mathrm{AGG})_{7}$ & 57 & PET & $140-149$ & LC462960 \\
\hline Eoxy029 & $\mathrm{F}$ & $\begin{array}{l}\text { F: CATGAGCCGTCTTTGTTTCA } \\
\text { R: GGGCTCTCGTAATGGGAAGT }\end{array}$ & $(\mathrm{AC})_{7}$ & 57 & FAM & $180-194$ & LC462961 \\
\hline Eoxy031 & $\mathrm{F}$ & $\begin{array}{l}\text { F: GAGGCAGTGAGAAATGGGTC } \\
\text { R: GACATGCCTGAACGAAACAA }\end{array}$ & $(\mathrm{AT})_{7}$ & 57 & PET & $238-248$ & LC462962 \\
\hline Eoxy101 & $\mathrm{C}$ & $\begin{array}{l}\text { F: CTGTATTCCATCGGAGAGGG } \\
\text { R: CTACTCGCACCTGTGTCGTC }\end{array}$ & $(\mathrm{CA})_{9}$ & 57 & VIC & 95-109 & LC462963 \\
\hline Eoxy 104 & B & $\begin{array}{l}\text { F: GGCGTCTGTGTACGACGTG } \\
\text { R: TGCAGCGGTAGTGATGAGTC }\end{array}$ & $(\mathrm{CCT})_{8}$ & 57 & VIC & $93-105$ & LC462964 \\
\hline Eoxy 116 & $\mathrm{E}$ & $\begin{array}{l}\text { F: GTGGCTCGACAGGTGAGAG } \\
\text { R: CACAAACGTCAAATCCCTTG }\end{array}$ & $(\mathrm{AGG})_{8}$ & 57 & PET & $98-110$ & LC462965 \\
\hline Eoxy 120 & $\mathrm{D}$ & $\begin{array}{l}\text { F: CTCTGTGGCGATAACAGCCT } \\
\text { R: ACATCCTCAGCTCCGAAAGG }\end{array}$ & $(\mathrm{AC})_{9}$ & 57 & FAM & $101-115$ & LC462966 \\
\hline Eoxy 123 & B & $\begin{array}{l}\text { F: TCAGGTCAGCAACATCATCA } \\
\text { R: CCTGTGGAATCACTGCTGAA }\end{array}$ & $(\mathrm{GT})_{8}$ & 57 & FAM & $102-108$ & LC462967 \\
\hline Eoxy 124 & $\mathrm{E}$ & $\begin{array}{l}\text { F: ACAAGGGAGGGTCATTTGAG } \\
\text { R: AGTTGCCATCCTTGTCCAAA }\end{array}$ & $(\mathrm{GT})_{9}$ & 57 & NED & $107-117$ & LC462968 \\
\hline Eoxy131 & $\mathrm{D}$ & $\begin{array}{l}\text { F: TTCCGGTATTTATGTTTGCAC } \\
\text { R: TGTGGCACAGTTGACAGGTT }\end{array}$ & $(\mathrm{ATT})_{10}$ & 57 & VIC & $104-116$ & LC462969 \\
\hline Eoxy 135 & A & $\begin{array}{l}\text { F: GAGTTGCGGAGACAGATTGC } \\
\text { R: GGTTGATCAGAGCTCGCAC }\end{array}$ & $(\mathrm{TC})_{9}$ & 57 & NED & $112-122$ & LC462970 \\
\hline Eoxy 136 & $\mathrm{D}$ & $\begin{array}{l}\text { F: TCTAACCACTGGTGCCATTT } \\
\text { R: CAGACGAGGATGAGAACATGC }\end{array}$ & $(\mathrm{CT})_{9}$ & 57 & PET & $120-124$ & LC462971 \\
\hline Eoxy139 & A & $\begin{array}{l}\text { F: TGCGTTCAGAGCTGCATTAT } \\
\text { R: CTCTAAGGCTTTAGCTCTGTGG }\end{array}$ & $(\mathrm{AC})_{11}$ & 57 & VIC & $110-120$ & LC462972 \\
\hline Eoxy 141 & $\mathrm{~F}$ & $\begin{array}{l}\text { F: CTACAGACCGAAGCACTGGG } \\
\text { R: CCAGTCCAGACTTTCCTTCCT }\end{array}$ & $(\mathrm{AG})_{9}$ & 57 & VIC & $116-124$ & LC462973 \\
\hline
\end{tabular}




\begin{tabular}{|c|c|c|c|c|c|c|c|}
\hline Eoxy145 & $\mathrm{C}$ & $\begin{array}{l}\text { F: GTTCACCATTTATCCATGCG } \\
\text { R: TGTGGCTGGAGAGTCTGACA }\end{array}$ & $(\mathrm{AC})_{10}$ & 57 & PET & $122-137$ & LC462974 \\
\hline Eoxy155 & G & $\begin{array}{l}\text { F: TTTGTCCCACGTGACTCG } \\
\text { R: CATCCTGCTGGTAGCACTGA }\end{array}$ & $(\mathrm{GT})_{10}$ & 57 & NED & $160-188$ & LC462975 \\
\hline Eoxy156 & G & $\begin{array}{l}\text { F: GCACAACACAATGTTACAGCG } \\
\text { R: TTCCTGATGGCTTCCTGTCT }\end{array}$ & $(\mathrm{AAG})_{8}$ & 57 & PET & $148-189$ & LC462976 \\
\hline Eoxy157 & B & $\begin{array}{l}\text { F: ATGCTTCACCTCCACAGAGC } \\
\text { R: AAGCCCAAATGGATTCTTCC }\end{array}$ & $(\mathrm{GT})_{9}$ & 57 & VIC & $171-193$ & LC462977 \\
\hline Eoxy158 & $\mathrm{C}$ & $\begin{array}{l}\text { F: CGGGAGATAGCGGTGTCTTA } \\
\text { R: CCACTGCTTGTATGTCTGCC }\end{array}$ & $(\mathrm{GT})_{9}$ & 57 & NED & $182-198$ & LC462978 \\
\hline Eoxy165 & D & $\begin{array}{l}\text { F: AAGTCTCCGGGTCATACTGC } \\
\text { R: CCCAACTCAGAGACGACACA }\end{array}$ & $(\mathrm{GT})_{9}$ & 57 & FAM & $187-195$ & LC462979 \\
\hline Eoxy168 & $\mathrm{E}$ & $\begin{array}{l}\text { F: TGAGATGACTCAGTGCCACC } \\
\text { R: TTTCACTCTCATCATCCACCA }\end{array}$ & $(\mathrm{AC})_{8}$ & 57 & FAM & $181-191$ & LC462980 \\
\hline Eoxy169 & $\mathrm{E}$ & $\begin{array}{l}\text { F: TTTAGCGTAATGGTCAGCCC } \\
\text { R: AATTGCACTTTACAGCACTTTG }\end{array}$ & $(\mathrm{AAT})_{9}$ & 57 & NED & 189-201 & LC462981 \\
\hline Eoxy172 & B & $\begin{array}{l}\text { F: CGTCTCTGAGAACACAGGCA } \\
\text { R: GGGAGTATACCTGTAAACCGGG }\end{array}$ & $(\mathrm{AG})_{10}$ & 57 & FAM & $182-194$ & LC462982 \\
\hline Eoxy 173 & D & $\begin{array}{l}\text { F: AGCGATGGTCAGAAGGAGC } \\
\text { R: GGTTTGGCAAATTTGTGAGG }\end{array}$ & $(\mathrm{CA})_{11}$ & 57 & NED & 203-219 & LC462983 \\
\hline Eoxy179 & D & $\begin{array}{l}\text { F: GGACGATGACTTTGTGTTCG } \\
\text { R: GCTTCAGGATTCTCACGAGG }\end{array}$ & $(\mathrm{AC})_{12}$ & 57 & VIC & $201-211$ & LC462984 \\
\hline Eoxy 180 & A & $\begin{array}{l}\text { F: GACTTCTCATTCTGCCCTGC } \\
\text { R: GGTTGACAGGGCTCGCTAT }\end{array}$ & $(\mathrm{CA})_{11}$ & 57 & NED & $214-230$ & LC462985 \\
\hline Eoxy 182 & B & $\begin{array}{l}\text { F: CCGAGAACATCTGCTGTAGTTT } \\
\text { R: GTCCTGCCGGGAATTTGT }\end{array}$ & $(\mathrm{TC})_{9}$ & 57 & NED & $213-221$ & LC462986 \\
\hline Eoxy 186 & A & $\begin{array}{l}\text { F: CAGTTGAGGGTGAATGAGGG } \\
\text { R: ATCCTGGCTCTCCGTCTGT }\end{array}$ & $(\mathrm{AC})_{8}$ & 57 & VIC & 214-224 & LC462987 \\
\hline Eoxy 189 & $\mathrm{~F}$ & $\begin{array}{l}\text { F: GCCTCAGACCCAAAGCAG } \\
\text { R: AGTTCACTGTCGGCAGGTTT }\end{array}$ & $(\mathrm{AGC})_{11}$ & 57 & VIC & 208-231 & LC462988 \\
\hline Eoxy192 & $\mathrm{F}$ & $\begin{array}{l}\text { F: AATGATTATCTAATGGTGATGATGG } \\
\text { R: TGTGAGCCTATTCCCACAAGT }\end{array}$ & $(\mathrm{GAT})_{8}$ & 57 & NED & $239-266$ & LC462989 \\
\hline Eoxy194 & $\mathrm{C}$ & $\begin{array}{l}\text { F: TCATTTATCAACACGGAGCA } \\
\text { R: TCCGCCTGATCATAGTAATCG }\end{array}$ & $(\mathrm{AC})_{9}$ & 57 & FAM & $251-264$ & LC462990 \\
\hline Eoxy196 & B & $\begin{array}{l}\text { F: AACCAGGCTCTGACATCACC } \\
\text { R: CTTGAGCCATGAAGGAATGG }\end{array}$ & $(\mathrm{AG})_{14}$ & 57 & FAM & $261-278$ & LC462991 \\
\hline
\end{tabular}

$T_{\mathrm{a}}$, Annealing temperature; ${ }^{\text {a }}$ Sequences of fluorescent labels: FAM $=5^{\prime}$-GCCTCCCTCGCGCCA-3', VIC $=5^{\prime}$-GCCTTGCCAGCCCGC-3', NED = 5'-CAGGACCAGGCTACCGTG-3', PET = 5'-CGGAGAGCCGAGAGGTG-3'.

al., 2014). Moreover, since the impact of climate change on genetic diversity and structure of sea-dispersed mangrove plants has been highlighted (Wee et al., 2019), this could also be expected in amphidromous fishes that use ocean currents.

The sleeper E. oxycephala Temminck and Schlegel, 1845 (Perciformes: Eleotridae) is an amphidromous fish (Xia et al., 2015) that lays eggs in the downstream sections of rivers. The larvae then flow down to the sea and, after drifting on ocean currents, juveniles swim upstream and mature in rivers (Suguro and Senou, 2006). This species is mainly distributed along the Kuroshio Current in East Asia, including southern Japan, Korea, Taiwan, southeastern China and Vietnam (Oshima, 1919; Akihito, 1967; Kottelat, 2001; Kim et al., 2014; Meng et al., 2016), and larvae are thought to disperse and be strongly affected by the Kuroshio Current (Yamakawa and Senou, 2015; Mashiko, 2016). The habitat of E. oxycephala has deteriorated due to human alterations such as dam construction, shore protection and water pollution in rivers 
(Suguro and Senou, 2006; Mashiko, 2016). Thus, this species is ranked as threatened or near-threatened in the red lists of 12 prefectures in Japan (e.g., 'Endangered' in the Red List of Kanagawa Prefecture (Suguro and Senou, 2006)). In addition, the Kuroshio Current is predicted to undergo increases in flow speed and frequency of great meandering due to global warming (Sakamoto et al., 2005), and there is concern about the effects this will have on the dispersal patterns and associated genetic diversity of $E$. oxycephala populations. To support the conservation of $E$. oxycephala, it is important to examine population genetic diversity and structure, as well as population demographic history in relation to the Kuroshio Current. For these examinations, we developed, for the first time, 40 microsatellite markers for $E$. oxycephala and tested their suitability using 43 individuals from two populations of the species.

We collected fresh caudal fin and muscle tissue samples from three individuals of $E$. oxycephala collected in the Sagami River in Kanagawa Prefecture. Genomic DNA was extracted from these samples using the DNeasy Blood \& Tissue Kit (Qiagen, Valencia, CA, USA). A DNA fragment library was constructed using the Ion Xpress Plus Fragment Library Kit (Thermo Fisher Scientific, Waltham, MA, USA), amplified using the Ion PGM Template OT2 400 Kit (Thermo Fisher Scientific), and subsequently sequenced using the Ion PGM Sequencing 400 Kit (Thermo Fisher Scientific) and an Ion 318 Chip v2 (Thermo Fisher Scientific) with the next-generation sequencer Ion PGM (Thermo Fisher Scientific). The total number of reads obtained was 676,672 . To identify microsatellite regions that contain more than seven di-, trior tetranucleotide repeats, we screened the reads using QDD (Meglécz et al., 2010, 2014) on the Galaxy (Afgan et al., 2018) virtual machine and Primer3 version 4.0.0 with default settings (Rozen and Skaletsky, 2000). A total of 127 primer pairs were designed.

Preliminary amplification tests for all 127 primer pairs were conducted using eight individuals from the following four populations of E. oxycephala in Japan: Sagami River in Kanagawa Prefecture, Shirutani River in the Miya River system in Mie Prefecture, Kuma River in the Kokubu River system in Kochi Prefecture, and Sarugase River in the Hitotsuse River system in Miyazaki Prefecture. PCR amplification with fluorescently labeled primers (Table 1) was performed following the method of Blacket et al. (2012) using the Qiagen Multiplex PCR Kit (Qiagen). Each reaction contained $10 \mathrm{ng}$ of extracted DNA, $2.5 \mu \mathrm{l}$ of Multiplex PCR Master Mix, $0.01 \mu \mathrm{M}$ fluorescently labeled forward primer, and $0.2 \mu \mathrm{M}$ fluorescently labeled universal primer and reverse primer in a final volume of $5.0 \mu \mathrm{l}$. The amplification process consisted of an initial denaturation at $95{ }^{\circ} \mathrm{C}$ for $15 \mathrm{~min}$; 31 cycles of denaturation at $94{ }^{\circ} \mathrm{C}$ for $30 \mathrm{~s}$, annealing at $57^{\circ} \mathrm{C}$ for $90 \mathrm{~s}$ and extension at $72{ }^{\circ} \mathrm{C}$ for $1 \mathrm{~min}$; and a final extension at
Table 2. Genetic variation of the 40 microsatellite loci for two populations of Eleotris oxycephala

\begin{tabular}{|c|c|c|c|c|c|c|}
\hline \multirow[t]{2}{*}{ Locus } & \multicolumn{3}{|c|}{$\begin{array}{c}\text { Sagami River } \\
\text { population }(N=29)\end{array}$} & \multicolumn{3}{|c|}{$\begin{array}{c}\text { Sarugase River } \\
\text { population }(N=14)\end{array}$} \\
\hline & $A$ & $H_{\mathrm{E}}$ & $F_{\text {IS }}$ & $A$ & $H_{\mathrm{E}}$ & $F_{\text {IS }}$ \\
\hline Eoxy002 & 9 & 0.752 & -0.055 & 8 & 0.816 & 0.037 \\
\hline Eoxy008 & 3 & 0.362 & 0.143 & 2 & 0.198 & -0.083 \\
\hline Eoxy009 & 4 & 0.675 & -0.022 & 4 & 0.593 & -0.083 \\
\hline Eoxy010 & 3 & 0.518 & -0.131 & 3 & 0.615 & 0.188 \\
\hline Eoxy013 & 10 & 0.848 & 0.187 & 10 & 0.860 & -0.163 \\
\hline Eoxy015 & 2 & 0.034 & 0.000 & 4 & 0.484 & 0.409 \\
\hline Eoxy016 & 2 & 0.409 & 0.325 & 2 & 0.511 & -0.258 \\
\hline Eoxy025 & 6 & 0.603 & 0.086 & 7 & 0.582 & 0.264 \\
\hline Eoxy027 & 4 & 0.670 & -0.081 & 4 & 0.687 & 0.376 \\
\hline Eoxy029 & 8 & 0.749 & 0.172 & 6 & 0.706 & 0.089 \\
\hline Eoxy031 & 4 & 0.622 & -0.053 & 4 & 0.659 & 0.025 \\
\hline Eoxy101 & 7 & 0.833 & 0.131 & 8 & 0.791 & 0.097 \\
\hline Eoxy 104 & 4 & 0.493 & -0.050 & 5 & 0.602 & 0.288 \\
\hline Eoxy116 & 3 & 0.504 & 0.316 & 3 & 0.629 & 0.092 \\
\hline Eoxy 120 & 9 & 0.808 & 0.019 & 6 & 0.813 & 0.209 \\
\hline Eoxy 123 & 2 & 0.448 & 0.000 & 3 & 0.442 & 0.031 \\
\hline Eoxy124 & 5 & 0.719 & -0.200 & 7 & 0.788 & -0.178 \\
\hline Eoxy 131 & 6 & 0.336 & -0.026 & 3 & 0.374 & 0.235 \\
\hline Eoxy 135 & 5 & 0.756 & -0.049 & 5 & 0.824 & 0.220 \\
\hline Eoxy136 & 3 & 0.442 & 0.219 & 3 & 0.563 & 0.112 \\
\hline Eoxy 139 & 4 & 0.607 & -0.023 & 3 & 0.544 & 0.212 \\
\hline Eoxy 141 & 5 & 0.782 & 0.339 & 5 & 0.761 & 0.061 \\
\hline Eoxy 145 & 7 & 0.751 & 0.082 & 5 & 0.687 & -0.248 \\
\hline Eoxy 155 & 9 & 0.833 & 0.048 & 7 & 0.783 & 0.088 \\
\hline Eoxy 156 & 9 & 0.797 & 0.265 & 7 & 0.852 & 0.245 \\
\hline Eoxy 157 & 7 & 0.783 & 0.119 & 4 & 0.736 & -0.261 \\
\hline Eoxy 158 & 9 & 0.825 & -0.003 & 7 & 0.819 & -0.134 \\
\hline Eoxy 165 & 5 & 0.745 & -0.018 & 5 & 0.725 & 0.212 \\
\hline Eoxy168 & 6 & 0.695 & 0.057 & 6 & 0.577 & 0.133 \\
\hline Eoxy 169 & 5 & 0.624 & 0.281 & 5 & 0.522 & 0.179 \\
\hline Eoxy 172 & 6 & 0.634 & 0.129 & 4 & 0.610 & -0.054 \\
\hline Eoxy173 & 8 & 0.818 & -0.011 & 7 & 0.838 & -0.023 \\
\hline Eoxy179 & 6 & 0.776 & -0.021 & 6 & 0.766 & -0.025 \\
\hline Eoxy180 & 7 & 0.772 & 0.018 & 6 & 0.805 & -0.154 \\
\hline Eoxy 182 & 3 & 0.555 & 0.069 & 3 & 0.264 & -0.083 \\
\hline Eoxy 186 & 5 & 0.681 & -0.063 & 3 & 0.374 & 0.044 \\
\hline Eoxy 189 & 8 & 0.808 & -0.067 & 7 & 0.783 & 0.088 \\
\hline Eoxy 192 & 7 & 0.750 & $0.448^{*}$ & 6 & 0.679 & 0.263 \\
\hline Eoxy 194 & 4 & 0.442 & -0.170 & 5 & 0.560 & -0.020 \\
\hline Eoxy 196 & 5 & 0.749 & 0.034 & 6 & 0.758 & 0.341 \\
\hline
\end{tabular}

$N$, number of analyzed individuals; $A$, number of alleles; $H_{E}$, expected heterozygosity; $F_{\mathrm{IS}}$, fixation index; * significant deviation from zero $(P<0.05)$. 
$60{ }^{\circ} \mathrm{C}$ for $30 \mathrm{~min}$. Fragment sizes were determined using an ABI PRISM 3130 Genetic Analyzer and Gene Mapper software (Applied Biosystems, Foster City, CA, USA) with GeneScan 600 LIZ dye Size Standard v2.0 (Applied Biosystems). Seven sets of multiplex PCR primer pairs (two to eight primer pairs per multiplex panel A-G) were designed for 40 selected loci (described below) (Table 1).

The genetic variation of the 40 selected loci (see below) was evaluated using 43 individuals from two populations of E. oxycephala in Japan: 29 individuals collected in Sagami River $\left(35^{\circ} 21^{\prime}-35^{\circ} 22^{\prime}\right.$ N/139 $22^{\prime}$ E) in Kanagawa Prefecture and 14 individuals collected in Sarugase River in the Hitotsuse River system $\left(32^{\circ} 03^{\prime} \mathrm{N} / 131^{\circ} 27^{\prime} \mathrm{E}\right)$ in Miyazaki Prefecture. For each population, the number of alleles $(A)$, expected heterozygosity $\left(H_{\mathrm{E}}\right)$ and fixation index $\left(F_{\text {IS }}\right)$ were calculated at each locus using FSTAT version 2.9.3 (Goudet, 1995). Deviations from HardyWeinberg equilibrium, as evidenced by $F_{\text {IS }}$ deviations from zero, and genotype disequilibrium among the 40 loci based on 1,000 randomizations were tested using FSTAT version 2.9.3. In addition, genetic differentiation between the two populations was evaluated by calculating $F_{\mathrm{ST}}$ (Weir and Cockerham, 1984) and its standardized value, $F_{\text {ST }}$, which always ranges from 0 to 1 (Meirmans and Hedrick, 2011), using GenAlEx version 6.5 (Peakall and Smouse, 2012). The significance of the $F_{\mathrm{ST}}$ value was tested by 999 permutations using GenAlEx.

Of the 127 primer pairs in the preliminary test, 40 yielded clear peak patterns based on eight individuals. All 40 of these primer pairs were then successfully amplified in all 43 individuals from two populations of $E$. oxycephala (Table 1). The range of $A$ was $2-10$ (mean = 5.350), indicating that all loci were polymorphic in both populations (Table 2). The ranges of $H_{\mathrm{E}}$ and $F_{\text {IS }}$ per locus were 0.034-0.860 (mean $=0.650)$ and $-0.261-$ $0.448($ mean $=0.065)$, respectively $($ Table 2$)$. Significant deviation of $F_{\text {IS }}$ values from zero was observed for only one locus, Eoxy192, in the Sagami River population $(P<$ 0.05 after Bonferroni correction, Table 2), probably due to a high frequency of null alleles. Significant genotype disequilibrium among the loci was not observed $(P>$ 0.05 after Bonferroni correction). Although significant $(P<0.05), F_{\mathrm{ST}}$ and $F_{\text {ST }}$, values between the two populations were 0.008 and 0.024 , respectively, suggesting very low genetic differentiation even though the geographic distance between the two populations was more than $800 \mathrm{~km}$. This indicated that E. oxycephala experiences widespread gene flow due to long-distance dispersal via the Kuroshio Current.

Overall, we developed 40 polymorphic microsatellite markers that will be useful for conservation genetics studies of $E$. oxycephala, including evaluation of genetic diversity and structure together with population demographic inference.

\section{REFERENCES}

Afgan, E., Baker, D., Batut, B., van den Beek, M., Bouvier, D., Čech, M., Chilton, J., Clements, D., Coraor, N., Grüning, B. A., et al. (2018) The Galaxy platform for accessible, reproducible and collaborative biomedical analyses: 2018 update. Nucleic Acids Res. 46, W537-W544.

Akihito, Prince. (1967) On four species of the gobiid fishes of the genus Eleotris found in Japan. Japan. J. Ichthyol. 14, 135-166 (in Japanese with English summary).

Blacket, M. J., Robin, C., Good, R. T., Lee, S. F., and Miller, A. D. (2012) Universal primers for fluorescent labelling of PCR fragments-an efficient and cost-effective approach to genotyping by fluorescence. Mol. Ecol. Resour. 12, 456-463.

Chang, Y.-L. K., Miyazawa, Y., Miller, M. J., and Tsukamoto, K. (2018) Potential impact of ocean circulation on the declining Japanese eel catches. Sci. Rep. 8, 5496.

Goudet, J. (1995) FSTAT (version 1.2): a computer program to calculate F-statistics. J. Hered. 86, 485-486.

IPCC (2013) Climate Change 2013: The Physical Science Basis. Contribution of Working Group I to the Fifth Assessment Report of the Intergovernmental Panel on Climate Change. Cambridge University Press, Cambridge, United Kingdom and New York.

Katano, O., Nakamura, T., Abe, S., Yamamoto, S., and Baba, Y. (2006) Comparison of fish communities between above- and below-dam sections of small streams; barrier effect to diadromous fishes. J. Fish Biol. 68, 767-782.

Kim, B., Jang, M., Yoon, J., and Song, H. (2014) First reliable record of an eleotrid fish, Eleotris oxycephala (Perciformes: Eleotridae) from the lower reach of Jwagwang stream near Busan, Korea. Korean J. Ichthyol. 26, 230-234.

Kottelat, M. (2001) Freshwater Fishes of Northern Vietnam: A Preliminary Check-List of the Fishes Known or Expected to Occur in Northern Vietnam with Comments on Systematics and Nomenclature. The World Bank, Washington, D.C., USA.

Kuriiwa, K., Chiba, S. N., Motomura, H., and Matsuura, K. (2014) Phylogeography of Blacktip Grouper, Epinephelus fasciatus (Perciformes: Serranidae), and influence of the Kuroshio Current on cryptic lineages and genetic population structure. Ichthyol. Res. 61, 361-374.

Mashiko, K. (2016) Kawaanago. In: Red Data Book 2016 Ibaraki. (ed.: Division of Environmental Policy, Department of Life Environment, Ibaraki Prefecture Government), p. 117. Ibaraki Prefectural Government, Mito, Japan (in Japanese).

Meglécz, E., Costedoat, C., Dubut, V., Gilles, A., Malausa, T., Pech, N., and Martin, J.-F. (2010) QDD: a user-friendly program to select microsatellite markers and design primers from large sequencing projects. Bioinformatics 26, 403-404.

Meglécz, E., Pech, N., Gilles, A., Dubut, V., Hingamp, P., Trilles, A., Grenier, R., and Martin, J. F. (2014) QDD version 3.1: a user-friendly computer program for microsatellite selection and primer design revisited: experimental validation of variables determining genotyping success rate. Mol. Ecol. Resour. 14, 1302-1313.

Meirmans, P. G., and Hedrick, P. W. (2011) Assessing population structure: $F_{\mathrm{ST}}$ and related measures. Mol. Ecol. Resour. 11, $5-18$.

Meng, Y., Ma, H., Ma, C., Wei, H., Liu, Y., Zhang, F., Wang, W., Chen, W., Zhao, M., Chen, F., et al. (2016) The complete mitochondrial genome of Eleotris oxycephala (Perciformes: Eleotridae). Mitochondrial DNA A DNA Mapp. Seq. Anal. 27, 3820-3821. 
Oshima, M. (1919) Contributions to the study of the freshwater fishes of the island of Formosa. Ann. Carnegie Mus. 12, $169-328$.

Peakall, R., and Smouse, P. E. (2012) GenAlEx 6.5: genetic analysis in Excel. Population genetic software for teaching and research-an update. Bioinformatics 28, 2537-2539.

Rozen, S., and Skaletsky, H. (2000) Primer3 on the WWW for general users and for biologist programmers. Methods Mol. Biol. 132, 365-386.

Sakamoto, T. T., Hasumi, H., Ishii, M., Emori, S., Suzuki, T., Nishimura, T., and Sumi, A. (2005) Responses of the Kuroshio and the Kuroshio Extension to global warming in a high-resolution climate model. Geophys. Res. Lett. 32, L14617.

Shaddick, K., Gilligan, D. M., Burridge, C. P., Jerry, D. R., Truong, K., and Beheregaray, L. B. (2011) Historic divergence with contemporary connectivity in a catadromous fish, the estuary perch (Macquaria colonorum). Can. J. Fish. Aquat. Sci. 68, 304-318.

Suguro, N., and Senou, H. (2006) Kisui-tansuigyorui. In: The Red Data species in Kanagawa Prefecture 2006. (eds.: Takakuwa, M., Katsuyama, T., and Kiba, H.), pp. 275298. Kanagawa Prefectural Museum of Natural History, Odawara, Japan (in Japanese).

Watanabe, S., Iida, M., Kimura, Y., Feunteun, E., and Tsukamoto,
K. (2006) Genetic diversity of Sicyopterus japonicus as revealed by mitochondrial DNA sequencing. Coastal Mar. Sci. 30, 473-479.

Wee, A. K. S., Mori, G. M., Lira, C. F., Núñez-Farfán, J., Takayama, K., Faulks, L., Shi, S., Tsuda, Y., Suyama, Y., Yamamoto, T., et al. (2019) The integration and application of genomic information in mangrove conservation. Conserv. Biol. 33, 206-209.

Weir, B. S., and Cockerham, C. C. (1984) Estimating F-statistics for the analysis of population structure. Evolution 38, $1358-1370$.

Xia, A., Zhong, L., Chen, X., Bian, W., Zhang, T., and Shi, Y. (2015) Complete mitochondrial genome of spined sleeper Eleotris oxycephala (Perciformes, Eleotridae) and phylogenetic consideration. Biochem. Syst. Ecol. 62, 11-19.

Yamakawa, U., Mitsui, S., Maruyama, T., Kato, S., Sakai, S., and Senou, H. (2018) Notes on eighteen fish species recorded from the rivers and coastal areas of Sagami Bay and adjacent waters, Japan: northward range extension of warm water fishes in recent years. Bull. Kanagawa Prefect. Mus. (Nat. Sci.) 47, 35-57 (in Japanese with English abstract).

Yamakawa, U., and Senou, H. (2015) The distributions of gobioid fishes of the genus Eleotris in the rivers of Kanagawa Prefecture. Natural History Report of Kanagawa 36, 63-68 (in Japanese with English abstract). 